\title{
Chromatographic detection of nitrofurans in foods of animal origin
}

\section{Detecção cromatográfica de nitrofuranos em alimentos de origem animal}

\author{
César Aquiles Lázaro de la Torre ${ }^{1 *}$, Juan Espinoza Blanco', Joab Trajano Silva², \\ Vânia Margaret Flosi Paschoalin², Carlos Adam Conte Júnior ${ }^{3}$
}

\begin{abstract}
Nitrofurans are antibacterials banned in livestock by different countries due to its relationship with the production of carcinogenic metabolites. Several studies have been conducted to find the best methodology to identify these residues. The objectives of this review work were to show the risk of nitrofuran metabolites (furazolidone; nitrofurazone; nitrofurantoin, furaltadone and nifursol); to explain the application of liquid chromatography and mass spectrometry to determine the presence of these residues in foods of animal origin; and, finally, to report some methodologies that were recently used in different foods of animal origin.
\end{abstract}

KEYWORDS: nitrofurans; liquid chromatography; mass spectrometry; meat; egg; milk; honey.
RESUMO: Nitrofuranos são antibacterianos proibidos na criação de animais por diferentes países devido a sua relação com a produção de metabolitos carcinogênicos. Vários trabalhos de pesquisa têm sido desenvolvidos para encontrar a melhor metodologia que possa identificar esses resíduos. O presente trabalho de revisão teve como objetivos mostrar o risco dos metabolitos dos nitrofuranos (furazolidona, nitrofurazona, nitrofurantoina, furaltadona e nifursol); explicar a aplicação da cromatografia líquida e da espectrometria de massas para determinar a presença desses resíduos em alimentos de origem animal; e, finalmente, relatar algumas metodologias usadas recentemente em alimentos de origem animal.

PALAVRAS-CHAVE: nitrofuranos; cromatografia líquida; espectrometria de massas; carne; ovos; leite; mel. 


\section{INTRODUCTION}

The use of nitrofurans in the farm industry has been banned in many countries around the world; this fact is especially owed to the risk of substantial residues in meat, milk, honey and others foods of animal origin (FERNÁNDEZ, 2004). The presence of veterinary antibiotic residues and its associated harmful health effects on humans turns the analytical control of these drugs into an important mechanism to ensure consumer protection (Shankar et al., 2010). Countries of the European Union have strictly regulated the use of veterinary drugs in food animal species, and some of them can be permitted only under specific circumstances (therapeutic purposes), but with the strict control and administration of a veterinarian specialist (ToldrÁ; ReIG, 2006; ReIG; ToldrÁ, 2008).

Sometimes, the identification of some drugs in foods is only possible through the presence of their metabolites, mostly presented in insignificant quantities. The chromatography associated with mass spectrometry is the best current method to detect and quantify the metabolites of nitrofurans (FInZI et al., 2005; VAss et al., 2008). Nowadays, different studie have been conducted to improve this technique in food matrices. In this review, we showed the application of liquid chromatography coupled to mass spectrometry to determine the nitrofuran metabolites in different foods of animal origin.

\section{Nitrofurans}

The nitrofurans, nitrofurantoin (NFT), furazolidone (FZD), nitrofurazone (NFZ), nifursol (NFS) and furaltadone (FTD) are a particular group of veterinary antibiotics that used to be much used for poultry, swine and cattle, fish, shrimp and bee farms (VAss et al., 2008). These antibiotics were used as feed additives for growth promotion, prophylactic and therapeutic treatment of bacterial and protozoan infections. These synthetic antibacterial drugs contain a characteristic 5-membered nitrofuran ring in their structure.
Nitrofurans are very effective to treat infections caused by bacteria and protozoa (by inhibiting glucose metabolism and ribosomal function). However, in 1995, the use of nitrofurans for livestock production was completely prohibited in the EU (Commission Regulation, 1995) due to concerns about the carcinogenicity of the drug residues and their potential harmful effects on human health (VAss et al., 2008). This prohibition was quickly adopted by several countries, such as Australia, Japan, USA, Philippines and Thailand (Khong et al., 2004).

In Brazil, the Normative Instruction n. 09 established the banishment for the use, fabrication, manipulation, commercialization and importation of nitrofurans and products that contain this group of antibiotics in the veterinary field. In that same year, the Brazilian Ministry of Agriculture added the nitrofuran metabolites in the National Program for Control of Residues and Contaminants in animal food products. (BrasiL, 2003a, b). These actions were established to avoid the exportation of contaminated food.

Since nitrofurans are quickly metabolized and have in vivo half-lives of only a few hours, they must be identified by their metabolites, which are highly stable. These compounds include 3-amino-2-oxazolidinone (AOZ), 3-amino-5-morpholinomethyl-2-oxazolidinone (AMOZ), 3,5-dinitro-salicylic acid hydrazine (DNSAH) semicarbazide (SEM), and 1-aminohydantoin (AHD) (Table 1).

Several studies have shown the potential mutagenicity effects of nitrofuran derivatives in bacterial and mammalian cells, which contributed with the inhibitions of DNA synthesis (Mccalla et al., 1971; Bryant; Mccalla, 1980). One example of this mechanism was explained by ONA et al. (2009). They proposed that the mutant gene uvrA, hypersensitive to nitrofurazone-induced DNA damage, can reduce its activity when this antibiotic is removed from the media. This condition reversed an inhibition of DNA synthesis by nitrofurazone.

According to VAss et al. (2008), mutagenicity and toxicity of nitrofurans are not only related to their abuse

Table 1. Nitrofurans, their metabolites and derivatization products: compound information and typical MS/MS conditions for the metabolites derivatized with 2-nitrobenzaldehyde (nitrophenyl derivatives).

\begin{tabular}{|c|c|c|c|c|c|}
\hline \multicolumn{6}{|c|}{ Nitrofuran parent compounds } \\
\hline Name & Furaltadone & Furazolidone & Nifursol & Nitrofurantoin & Nitrofurazone \\
\hline Formula & $\mathrm{C}_{13} \mathrm{H}_{16} \mathrm{~N}_{4} \mathrm{O}_{6}$ & $\mathrm{C}_{8} \mathrm{H}_{7} \mathrm{~N}_{3} \mathrm{O}_{5}$ & $\mathrm{C}_{12} \mathrm{H}_{7} \mathrm{~N}_{5} \mathrm{O}_{9}$ & $\mathrm{C}_{8} \mathrm{H}_{6} \mathrm{~N}_{4} \mathrm{O}_{5}$ & $\mathrm{C}_{6} \mathrm{H}_{6} \mathrm{~N}_{4} \mathrm{O}_{4}$ \\
\hline \multicolumn{6}{|c|}{ Nitrofuran metabolites } \\
\hline \multirow{2}{*}{ Name } & 3-Amino-5-morpholinomethyl- & 3-Amino-2-oxazolidinone & 3,5-Dinitrosalicylic & 1-Aminohydantoin & Semicarbazide \\
\hline & 2-oxazolidinone & & acid hydrazide & & \\
\hline Acronym & AMOZ & $\mathrm{AOZ}$ & DNSAH & AHD & SEM \\
\hline Formula & $\mathrm{C}_{8} \mathrm{H}_{15} \mathrm{~N}_{3} \mathrm{O}_{3}$ & $\mathrm{C}_{3} \mathrm{H}_{6} \mathrm{~N}_{2} \mathrm{O}_{2}$ & $\mathrm{C}_{7} \mathrm{H}_{6} \mathrm{~N}_{4} \mathrm{O}_{6}$ & $\mathrm{C}_{3} \mathrm{H}_{5} \mathrm{~N}_{3} \mathrm{O}_{2}$ & $\mathrm{CH}_{5} \mathrm{~N}_{3} \mathrm{O}$ \\
\hline \multicolumn{6}{|c|}{ Nitrophenyl (NP) derivatives of nitrofuran metabolites } \\
\hline Acronym & NP-AMOZ & NP-AOZ & NP-DNSAH & NP-AHD & NP-SEM \\
\hline Formula & $\mathrm{C}_{15} \mathrm{H}_{18} \mathrm{~N}_{4} \mathrm{O}_{5}$ & $\mathrm{C}_{10} \mathrm{H}_{9} \mathrm{~N}_{3} \mathrm{O}_{4}$ & $\mathrm{C}_{14} \mathrm{H}_{9} \mathrm{~N}_{5} \mathrm{O}_{8}$ & $\mathrm{C}_{10} \mathrm{H}_{8} \mathrm{~N}_{4} \mathrm{O}_{4}$ & $\mathrm{C}_{8} \mathrm{H}_{8} \mathrm{~N}_{4} \mathrm{O}_{3}$ \\
\hline
\end{tabular}

Source: Adapted from MASTOVSKA (2011). 
in livestock production, but special attention has also been devoted to the toxicology of semicarbazide, which has been found in food produced from raw materials not subjected to nitrofurazone administration. HoENICKE et al. (2004) suggested that SEM detection in eggs and shrimp does not always come from the use of nitrofurazone in liverstock. The study showed that it is possible to form SEM after the use of hypochlorite commonly used in food processing for disinfection or bleaching.

\section{Liquid chromatography-mass spectrometry}

Most laboratories agree that the best method to identify nitrofuran metabolites is the system combining liquid chromatography (LC) with mass spectrometry (MS). This method allows the simultaneous screening-confirmatory technique of nitrofurans and substantially improves the reduction of time analysis (ToldRÁ; ReIG, 2006). However, some reagents are suitable to particular animal food matrices and this could interact in different ways with the preparation steps to LC/ MS/MS. In 2003, the European Union established a minimum required performance limit (MRPL) of $1 \mathrm{mg} / \mathrm{kg}$ for the nitrofuran metabolites in poultry meat and aquaculture products (MastovsKa, 2011)

In the past, the LC analysis was employed for the analysis of antibiotic residues using two main detectors: ultraviolet (UV) and fluorescence detector (FLD), with derivatization agents. The development of atmospheric pressure ionization (API) interfaces (e.g., electrospray ionization and atmospheric pressure chemical ionization) enabled the increasing use of mass spectrometric detection. Currently, mass spectrometry plays an important role in the analysis of antibiotic residues due to its accuracy, sensitivity and speed (Niessen, 2010). Tandem mass spectrometry (MSMS) has emerged as the most advisable technique for regulatory purposes, not only because it constitutes the most powerful detection mode in the analysis of compounds at the required residue level, but also because it can be used as a confirmatory technique, since it provides unequivocal structural information. This technique includes some parameters associated with ionization sources, analyzers, and acquisition (Chen; FANG, 2011).

\section{Liquid Chromatography}

This technique can be defined as a separation method in which the substances (nitrofurans) are injected in the LC system when the mobile phase (liquid solvent) carries the sample, which is separated in a stationary phase (chromatographic column). The chromatographic process occurs as a result of interaction and affinity during the movement of the analytes along the stationary phase (Niessen, 2010). Figure 1 shows the main components of liquid chromatography.

\section{Ionization resources}

Since the MS detection is only possible when the antibiotics exist as ions in the gaseous state, the coupling of LC to MS requires the volatilization of these biomolecules from the LC eluent. Nowadays, the electrospray ionization (ESI) and the atmospheric pressure chemical ionization (APCI) are accepted as LC-MS interfaces. In ESI sources, charged droplets are formed by spraying the sample solution through a high voltage $(2-5 \mathrm{kV})$ capillary at the presence of a strong electric field. The charged droplets move toward the mass

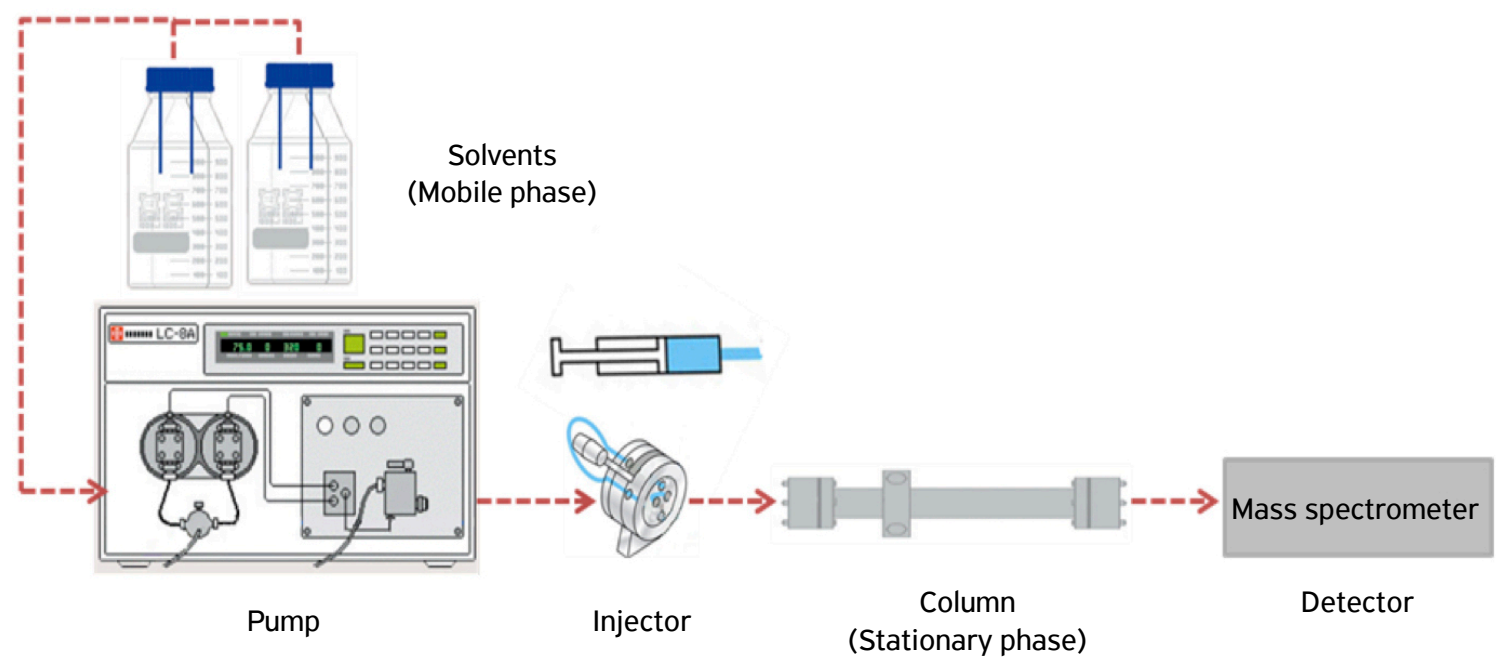

(ARDREy, 2003; Niessen, 2010).

Figure 1. Diagram of the liquid chromatography system. 
spectrometer inlet, generating analyte ions during evaporation and droplet fission. In APCI, a heated pneumatic probe is used for nebulization and a high voltage needle is used to produce a corona discharge for ionization of the evaporated solvent, reacting with the analyte.

\section{Mass analyzer}

The strength of mass spectrometry as a technique is that it can provide both the molecular weight of an analyte (the single most discriminating piece of information in structure elucidation) and information concerning the structure of the molecule involved. The ionization techniques that are mostly used for LC-MS, however, are called 'soft ionization', since they primarily produce molecular species with little fragmentation. It is unlikely that the molecular weight alone will allow a structural assignment to be made. Therefore, it is desirable to be able to generate structural information from such techniques (Ardrey, 2003; Niessen, 2010).

The linear quadrupole mass analyser is the most used system in nitrofurans analyses. This analyser consists of four hyperbolic or cylindrical rods that are placed side by side in a radial array. Opposite rods are charged by a positive or negative direct-current (DC) potential at which an oscillating radiofrequency $(\mathrm{RF})$ alternating-current voltage is superimposed. Ions are introduced into the quadrupole field and start to oscillate in a plane that is perpendicular to the quadrupole filter. Only the ions of one particular mass-to-charge ratio $(\mathrm{m} / \mathrm{z})$ follow stable trajectories. On the other hand, all of the other ions that do not have a stable trajectory will collide with the quadrupole rods and never reach the detector (ARdrey, 2003; NiEssen, 2010). The modern methods of ionization have poor ion fragmentation power. In these cases, it would be possible to use another quadrupole system to induced fragmentation by collision. This system, named triple quadrupole, can be observed in Fig. 2.

\section{Information from mass spectrometry}

A complete mass spectrum by determining the $\mathrm{m} / \mathrm{z}$ ratios and relative numbers of each one of the ions is obtained. Information can be useful for identification purposes and for determining the amount of an analyte. According to ARDREY (2003), the analyte identification is the result of the $\mathrm{m} / \mathrm{z}$ ratios. This information is saved into the program and used to scan further spectrum. On the other hand, quantitation in mass spectrometry is no different from other techniques that compare the results with standards containing known amounts/ concentrations of analytes.

\section{LC-MS/MS methodology used in foods of animal origin}

Various sample preparation methods prior to the analysis have been reported for a large variety of matrices such as in animal feeds (VAss et al., 2008). Considering the complexity of the matrix, the LC-MS/MS is adopted for this analysis. This method is suitable for foods of animal origin, such as aquatic products, muscles, tissues, and eggs (CHEN; FANG, 2011). A detailed methodology is briefly explained as follows:

- Materials: pure water, methanol, acetonitrile, ethyl acetate, dipotassium hydrogen phosphate trihydrate, formic acid, DMSO, 2-nitrobenzaldehyde (2-NBA), potassium phosphate dibasic $(0.1 \mathrm{~mol} / \mathrm{L}), \mathrm{HCl}(0.1 \mathrm{~mol} / \mathrm{L}), \mathrm{NaOH}$ (1 mol/L).

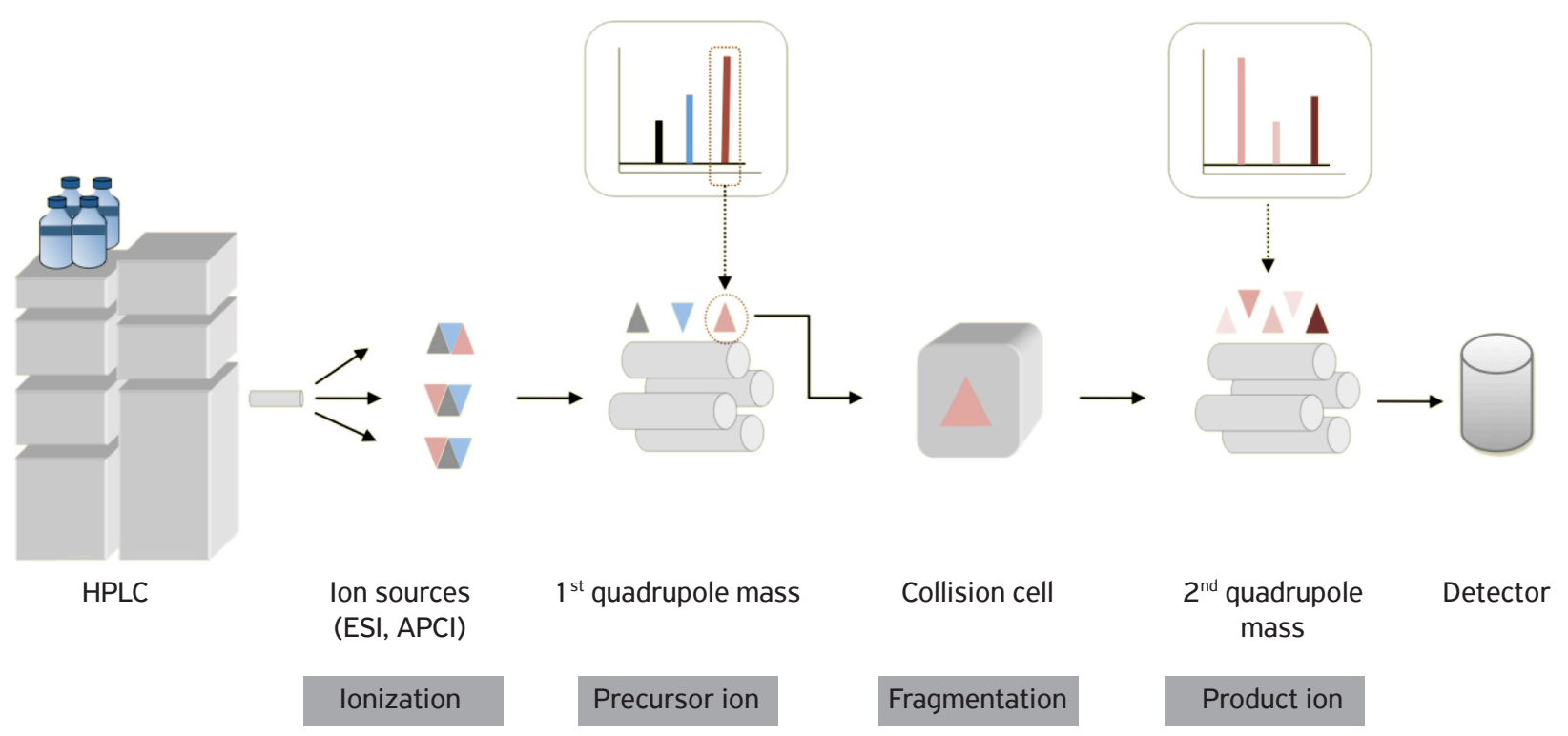

HPLC: High performance liquid chromatography; ESI: Electro-spray ionization; APCI: Atmospheric pressure chemical ionization. Figure 2. Scheme of the basic components of a triple quadrupole mass spectrometry. 
- Standards: AMOZ (FW201.11), AOZ (FW102.04), AHD, (FW115.04), SEM (FW75.043). Internal standards: $A M O Z-D_{5}, A O Z-D_{4}, A H D-{ }^{13} \mathrm{C}_{3}$, SEM- $-{ }^{13} \mathrm{C}_{15} \mathrm{~N}_{2}$ : purity $98 \%$.

- Instrument: LC-MS/MS with ESI source, vortexer, highspeed centrifuge $(15,093 \times \mathrm{g})$, $\mathrm{pH}$ meter.

- Sample preparation: weight $1 \mathrm{~g}$ of sample into a $50 \mathrm{~mL}$ centrifuge tube, and add $50 \mu \mathrm{L}$ of internal standards. Let it stand for $15 \mathrm{~min}$. Add $10 \mathrm{~mL} 0.125 \mathrm{M} \mathrm{HCl}$ sol., $100 \mathrm{~mL}$ $0.05 \mathrm{M}$ 2-NBA sol., mix gently. Incubate in water bath $\left(37^{\circ} \mathrm{C}\right.$ for 16 hours). Cool down at room temperature. Adjust to $\mathrm{pH} 7.4$ with $10 \mathrm{~mL} 0.1 \mathrm{M}$ potassium phosphate and $500 \mathrm{~mL} 0.8 \mathrm{M} \mathrm{NaOH}$. Centrifuge at $4,000 \mathrm{rpm}$ $(3,488 \times g)$ for 5 minutes and transfer the supernatant into a new tube. Add $10 \mathrm{~mL}$ of hexane, mix and centrifuge at $4,000 \mathrm{rpm}(3,488 \times g)$ for 5 minutes. Transfer the aqueous lower phase into a new tube. Add $7 \mathrm{~mL}$ of ethyl acetate and centrifuge at 4,400 $\mathrm{rpm}(4,221 \times g)$ for 10 minutes. Transfer the supernatant into a glass tube, repeat the operation twice. Evaporate to dryness under $\mathrm{N}_{2}$ $\left(40^{\circ} \mathrm{C}\right)$. Dissolve with $0.5 \mathrm{~mL} \mathrm{50 \%} \mathrm{methanol:water.} \mathrm{Filter}$ with $0.2 \mathrm{~mm}$ nylon syringe filter. Inject into LC-MS or

Table 2. Multiple reaction monitoring set for metabolites of nitrofurans.

\begin{tabular}{lcc} 
Name & Quantitation ion $(\mathrm{m} / \mathrm{z})$ & Qualifier ion $(\mathrm{m} / \mathrm{z})$ \\
\hline AMOZ & $335.3 / 291.2$ & $335.3 / 262.2$ \\
\hline AOZ & $236.1 / 134.1$ & $236.1 / 104.0$ \\
\hline AHD & $249.1 / 134.1$ & $249.1 / 178.1$ \\
\hline SEM & $209.1 / 166.2$ & $209.1 / 192.1$ \\
\hline AMOZ-D & $340.2 / 296.4$ & \\
\hline AOZ-D & $240.1 / 134.0$ & \\
\hline AHD-C & $252.1 / 134.1$ & \\
\hline SCA- ${ }_{3}{ }^{3} \mathrm{C}-{ }^{15} \mathrm{~N}_{2}$ & $212.1 / 168.2$ &
\end{tabular}

m/z: mass-to-charge ratio. Source: CHEN; FANG (2011).
LC-MS/MS. Note: adjust the same $\mathrm{pH}$ of both samples solution and standard solutions.

- LC settings: Column: C18 (100 mm × $4.6 \mathrm{~mm} \times 3.5 \mu \mathrm{m})$, column temp: $35^{\circ} \mathrm{C}$, injection volume: $20 \mathrm{~mL}$, mobile phase: methanol-ammonium acetate $\left(\mathrm{NH}_{4} \mathrm{OAc}\right)$ buffer (45:55), flow rate: $0.4 \mathrm{~mL} / \mathrm{min}$, stop time: $10 \mathrm{~min}$.

- MS-MS settings: Ion Source: ESI, scan mode: positive and multiple reaction monitoring (MRM) transition and collision energies are given in Table 2.

Generally, the sample preparation procedure for the LC-MS analysis involves homogenization, acid hydrolysis, derivatization and extraction. Solvent extraction is a commonly used method for nitrofurans. There are two kinds of extraction procedures: solid phase extraction (SPE) and liquidliquid extraction (LLE) with ethyl acetate and LC-MS/MS analysis usually performed in food samples. Tissue bound nitrofuran metabolites are small molecular species which are usually derivatized with 2-NBA in order to increase molecular mass and improve the sensitivity of detection; when necessary, a cleaning step using a non-polar solvent such as hexane is used to remove lipids from sample before detection (Conneely et al., 2002; Vass et al., 2008). Actually, is also important to develop methods with an easy, rapid, and lowcost sample preparation approach. This approach is known as QuEChERS, which stands for "quick, easy, cheap, effective, rugged, and safe" (Lehotay, 2011).

Before derivatisation, the release of bound metabolites from tissues is carried out under mildly acidic conditions (Fig. 3). Sample preparation based on this approach provides data on the total amount (free and bound) of nitrofuran metabolites in the tissue. The resulting nitrophenyl (NP) derivatives of the respective metabolites are separated from a sample using various extraction methods (VAss et al., 2008).

A<smiles></smiles>

Nitrofurazone<smiles>CC(C)/C=N/NC(N)=O</smiles>

Tissue bound SEM
B<smiles>CC(C)/C=N/NC(N)=O</smiles>

Tissue bound SEM

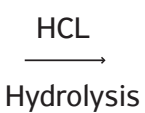<smiles>NNC(N)=O</smiles>

SEM<smiles>O=Cc1ccccc1[N+](=O)[O-]</smiles>

o-NBA<smiles>NC(=O)N/N=C/c1ccccc1[N+](=O)[O-]</smiles>

NPSEM

SEM: semicarbazide; NPSEM: 3[(2-nitrophenyl)methylene]-hydrazinecarboxamide; o-NBA: ortho-nitrobenzaldehyde. Source: VASS et al. (2008).

Figure 3. In vivo formation of tissue bound SEM (A). Release of bound SEM under mildly acidic conditions followed by SEM derivatisation to produce target analyte (B). 
According to references consulted in this review, it is very common to use the same methodology for nitrofuran metabolites in different matrices of food origin. Most of them try to improve the time of extraction, derivative reagent, limit of detection and others. Phongvivat (2004) showed the limits of nitrofuran metabolites established in some countries (Table 3 ). Table 3 summarizes some methods performed in the principal food of animal origin. The reader realizes that all of them reported limits of detection and quantification that were lower than those required by these countries.

\section{Shrimp}

Several methods to determine nitrofuran residues in foods of animal origin have been developed. CHU; Lopez (2005) used a methodology to determine the bound residues of the nitrofuran drugs in shrimp. In this procedure, shrimp tail samples were prewashed with metanol hexane and ethyl acetate, followed by overnight acid hydrolysis $(0.125 \mathrm{mM}$ $\mathrm{HCl}$ ), during which the side chains of the bound residues were released. Simultaneously, the residues were derivatized with 2-NBA. After liquid-liquid extraction cleanup, the derivatives were detected and quantitated using liquid chromatography-mass spectrometry/mass spectrometry (LC-MS/MS) with an atmospheric pressure chemical ionization interface. Results of validation showed limits of quantitation ranging from 0.1 to $0.5 \mathrm{ng} / \mathrm{g}$ for AOZ, SEM, AHD and Amoz. An et al. (2012) used a similar method including 16 hour of extraction with $0.125 \mathrm{mM} \mathrm{HCl}$ and ethyl acetate, derivatization with 2-NBA and analysis by LC-MS/MS in the atmospheric pressure chemical ionization mode. In this case, the limits of detection ranged from 0.05 to $0.2 \mathrm{ng} / \mathrm{g}$ for the same groups of metabolites. Chumanee et al. (2009) compared two kinds of detectors: diode array and mass spectrometry. They also tested a 2-naphthaldehyde (2-NTA), a new derivatizing reagent for the analysis of furazolidone, furaltadone, nitrofurazone, and nitrofurantoin metabolites in three commercial shrimps: giant freshwater shrimp (Macrobrachium resenbergii), white

Table 3. Reporting limits of nitrofuran metabolites expressed in $\mu \mathrm{g} / \mathrm{kg}$.

\begin{tabular}{lcccc} 
& AOZ & AMOZ & ADH & SEM \\
Netherlands & 0.5 & 0.5 & & \\
\hline UK & 1.0 & 1.0 & 1.0 & 1.0 \\
\hline France & $0.1-0.5$ & $0.1-0.5$ & $0.1-0.5$ & $0.1-0.5$ \\
\hline Belgium & 1.0 & 1.0 & 1.0 & 1.0 \\
\hline Italy & 1.0 & 1.0 & 1.0 & 1.0 \\
\hline Northern Ireland & 0.3 & 0.3 & 0.3 & 1.0
\end{tabular}

AOZ: 3-amino-2-oxazolidinone; AMOZ: 3-amino-5-morpholino-methyl1,3-oxa-zolidinone; AHD: 1-aminohydantoin; SEM: semicarbazide. Source: PHONGvivat (2004). leg shrimp (Litopenaeus Vannamei) and giant tiger prawn (Penaeus monodon), purchased in Bangkok. The extraction was performed with a solution of $0.2 \mathrm{M} \mathrm{HCl}, 2-\mathrm{NTA}$, methanol and ethyl acetate. Limits of detection ranged between $0.1-0.2 \mathrm{ng} / \mathrm{g}$. In this research, the authors concluded that 2-naphthaldehyde and both detectors were suitable for derivative reagents and quantification of nitrofuran metabolites in shrimp samples.

\section{Poultry}

In poultry meat, Verdon et al. (2007) validated a method to detected five nitrofuran metabolites in turkey muscle with emphasis on DNSAH, metabolite of nifursol. The method showed the same steps for extraction $(1 \mathrm{M} \mathrm{HCl}$, methanol) and derivatization (2-NBA) to detect nitrofuran metabolites in food matrices. However, a change was proposed in incubation time, from 16 hours at $37^{\circ} \mathrm{C}$ to 4 hours at $55^{\circ} \mathrm{C}$. This modification was interesting because no significant changes were reported in the samples tested and the same limits of detection $(<0.5 \mathrm{ng} / \mathrm{g})$ were reported. These changes can easily be extended from turkey muscle tissue to other poultry species and also to other matrices, such as honey, whole egg and pork meat. In other study, BARBOSA et al. (2011) studied the presence of furaltadone and nifursol and their metabolites applying the standard methodology (previously described in the LC-MS/MS section) in edible tissues (muscle, liver, and gizzards) of chickens after the administration of therapeutic and sub-therapeutic concentrations of both compounds. They concluded that the gizzard could be considered a selected matrix for nitrofuran residue evaluation in poultry due to its ability to retain both nitrofuran parent compounds and metabolites in higher concentrations, regardless of the administered dose or the suggested withdrawal time period.

The indirectly contamination of chicken meat products by additives have been reported in Brazil. Pereira et al. (2004) detected SEM in chicken meat samples. However, the origin of this metabolite was related to the flour used to coat the meat. For this reason, a study was conducted to trace possible sources of food contamination by SEM and several samples of commercial flours were positive for this metabolite. The contamination of SEM was associated to azodicarbonamide, drug that is used in the cereal industry as a flour improvement agent. These results demonstrate the need for developing detailed studies before the establishment of international analytical protocols for the residue analysis in processed animal food.

\section{Eggs}

FInZI et al. (2005) developed a fast, sensitive and reliable LC-MS/MS method to simultaneously analyze the metabolites of four commonly used nitrofuran drugs: NFT, FZD, 
NFZ and FTD for egg and poultry muscle. The sample cleanup was performed by a single liquid-liquid extraction step, after the hydrolysis $(\mathrm{HCl})$ and derivatisation (2-NBA) process. Molecules were separated by liquid chromatography in a C18 column $(100 \mathrm{~mm} \times 2.1 \mathrm{~mm}, 4 \mu \mathrm{m})$ at room temperature. The quantitative and confirmatory determination of these metabolites was performed by multiple reaction monitoring (MRM). Limits of quantification of $0.5 \mathrm{ng} / \mathrm{g}$ were achieved and the total analysis was accomplished in 5 minutes. On the other hand, Mccracken; KenNedy (2007) validated a LC-MS/MS method to determine nitrofuran metabolites (AOZ, AMOZ, SEM and AHD) in eggshell, albumen and yolk. Althouhg all egg parts showed residues of nitrofurans, the eggshell could be the part with more relevant residues, specially with SEM, which showed a $50 \%$ of the total. They concluded that this may be a problem if eggshell products reached the consumer such as source of calcium.

\section{Milk}

For dairy products, it is important to cite the work of Chu; Lopez (2007). They used the same methodology explained with shrimp matrices. Briefly, overnight acid hydrolysis with $\mathrm{HCl}$ and simultaneous derivatization with 2-NBA were performed in milk of dairy cows. During hydrolysis, the bound metabolites were hydrolyzed to the side chains. After $\mathrm{pH}$ adjustment and solid-phase extraction cleanup, the derivatives were detected and quantitated using a liquid chromatography-tandem mass spectrometry system with an APCI interface. One important difference from the shrimp method was the use of hexane to complete the separation and to remove the ethyl acetate from the aqueous phases. Suitable limits of quantification $(0.2 \mathrm{ng} / \mathrm{g})$ were determined for this method.

\section{Honey}

Lopez et al. (2007) showed that the same methodologies used by Chu; Lopez (2007) for milk could be useful to determine nitrofurans in honey. Another similar method for the simultaneous analysis of NFT, FZD, NFZ and FTD in honey samples was reported by KHONG et al. (2004); it was only different by using the ESI interface. This method has been validated in honey according to the European Union criteria for the analysis of veterinary drug residues in food, and had been successfully applied in a survey of honeys of various geographical origins, showing that furazolidone is the main nitrofuran antibiotic administered to treat bacterial diseases of bees (Mccracken; Kennedy, 2007).

\section{Fish}

CHu et al. (2008) evaluated the depletion of the nitrofuran drugs furazolidone, nitrofurazone, furaltadone, and nitrofurantoin, and their tissue-bound metabolites (3-amino-2-oxazolidinone, semicarbazide, 3-amino-5morpholinomethyl-2-oxazolidinone, and 1-aminohydantoin, respectively, in the muscle of channel catfish following oral dosing ( $1 \mathrm{mg} / \mathrm{kg}$ body weight). They concluded that parent drugs were rapidly eliminated from the muscle, and tissue concentrations fell below the limit of detection $(1 \mathrm{ng} / \mathrm{g})$ at 96 hours. Meanwhile, levels of tissue-bound metabolites were measurable for up to 56 post-dose days. These results support the use of tissue bound metabolites as target analytes for monitoring nitrofuran drugs in channel catfish.

\section{Other meats}

SaAri; Peltonen (2004) reported that semicarbazide can be detected in Finnish crayfish samples, but this crustaceans have bever been medicated with nitrofurazone. The researchers suggested that the origin of the semicarbazide is not clear, but one can rule out the illegal use of 5-nitrofurazone and the possible sample contamination with azodicarbonamide (ADC) during the sample handling and processing. Another hypothesis involves the route of formation and natural presence of SEM in crayfish, and they concluded the analysis with an interest question: is SEM formed while cooking crayfish or is it a natural constituent of this crustacean? On the other hand, an interesting approach using animal plasma (bovine, ovine, equine and porcine) in the detection of these metabolites had been developed and proposed as an alternative method for on-farm surveillance by Radovnikovic et al. (2011).

\section{CONCLUSION}

The use of nitrofurans in livestock is banned in several countries, especially for being a risk for human health. This fact led to the creation of various agencies that monitor these residues in the food trade. Researchers all over the world try to focus their work on developing a simple, accurate and reliable methodology to determine the nitrofuran metabolites in different food matrices of animal origin (meat, milk, egg and honey). The review showed that most methodologies can be used for different foods only with changes in the time of hydrolysis and kind of ionization. Furthermore, LC-MS/MS is the most used technique because it can detect minimal values of these metabolites. 


\section{REFERENCES}

AN, H.; HENRY, M.; CAIN, T.; TRAN, B.; PAEK, H. C.; FARLEY, D. Determination of total nitrofuran metabolites in shrimp muscle using liquid chromatography/tandem mass spectrometry in the atmospheric pressure chemical ionization mode. Journal of $A O A C$ International, v.95, n.4, p.1222-1233, 2012.

ARDREY, R.E. Liquid Chromatography - Mass Spectrometry: an introduction. Wiley, 2003.

BARBOSA, J.; FREITAS, A.; MOURA, S.; MOURÃO, J. L.; NORONHA DA SILVEIRA, M. I.; RAMOS, F. Detection, accumulation, distribution, and depletion of furaltadone and nifursol residues in poultry muscle, liver, and gizzard. Journal of Agricultural and Food Chemistry, v.59, n.22, p.11927-11934, 2011.

BRASIL. Instrução Normativa n 9. MAPA. Brasilia: Diario Oficial da União, 2003a.

BRASIL. Programa Nacional de Análise de Resíduos de Medicamentos Veterinários em Alimentos Expostos ao Consumo2004/2005. SANITÁRIA, A. N. D. V. Brasil: ANVISA 2003b.

BRYANT, D.W.; MCCALLA, D.R. Nitrofuran induced mutagenesis and error prone repair in Escherichia coli. Chemico-Biological Interactions, v.31, n.2, p.151-166, 1980.

CONNEELY A.; NUGENT A.; O’KEEFFE, M. Use of solid phase extraction for the isolation and clean-up of a derivatised furazolidone metabolite from animal tissues. Analyst, v.6, p.705-709, 2002.

CHEN, G.L.; FANG, Y.Y. The LC-MS/MS methods for the determination of specific antibiotics residues in food matrices. In: ZWEIGENBAUM, J. (ed.). Mass Spectrometry in Food Safety Methods and Protocols. Wilmington: Humana Press - Springer: 2011 . p.309-355.

CHU, P.S.; LOPEZ, M.I. Liquid chromatography-tandem mass spectrometry for the determination of protein-bound residues in shrimp dosed with nitrofurans. Journal of Agricultural and Food Chemistry, v.53, n.23, p.8934-8939, 2005.

CHU, P.S.; LOPEZ, M.I. Determination of nitrofuran residues in milk of dairy cows using liquid chromatography-tandem mass spectrometry. Journal of Agricultural and Food Chemistry, v.55, n.6, p.2129-2135, 2007.

CHU, P.S.; LOPEZ, M.I.; ABRAHAM, A.; EL SAID, K.R.; PLAKAS, S.M. Residue depletion of nitrofuran drugs and their tissue-bound metabolites in channel catfish (Ictalurus punctatus) after oral dosing. Journal of Agricultural and Food Chemistry, v.56, n. 17, p.8030-8034, 2008.

CHUMANEE, S.; SUTTHIVAIYAKIT, S.; SUTTHIVAIYAKIT, P. New reagent for trace determination of protein-bound metabolites of nitrofurans in shrimp using liquid chromatography with diode array detector. Journal of Agricultural and Food Chemistry, v.57, n.5, p.1752-1759, 2009.

FERNANDEZ, A. International trade of animal food products from South American Countries: Case of detection of residues of banned veterinary drugs. In: FAO/WHO (Ed.). Technical Workshop on Residues of Veterinary Drugs Without ADI/MRL. Rome, Italy: FAO Publishing Management Service: 2004. p.65-67.

FINZI, J. K.; DONATO, J. L.; SUCUPIRA, M.; DE NUCCI, G. Determination of nitrofuran metabolites in poultry muscle and eggs by liquid chromatography-tandem mass spectrometry. Journal of Chromatography B, v.824, n. 1-2, p.30-35, 2005.

HOENICKE, K.; GATERMANN, R.; HARTIG, L.; MANDIX, M.; OTTE, $\mathrm{S}$. Formation of semicarbazide (SEM) in food by hypochlorite treatment: is SEM a specific marker for nitrofurazone abuse? Food Additives and Contaminants, v.21, n.6, p.526-537, 2004.

KHONG, S.P.; GREMAUD, E.; RICHOZ, J.; DELATOUR, T.; GUY, P.A.; STADLER, R.H.; MOTTIER, P. Analysis of matrix-bound nitrofuran residues in worldwide-originated honeys by isotope dilution highperformance liquid chromatography-tandem mass spectrometry. Journal of Agricultural and Food Chemistry, v.52, n. 17, p.5309-5315, 2004.

LEHOTAY, S.J. QuEChERS sample preparation approach for mass spectrometric analysis of pesticide residues in foods. In:ZWEIGENBAUM, J. (Ed.). Mass Spectrometry in Food Safety Methods and Protocols. Wilmington, DE: Humana Press - Springer: 2011 . p.65-91.

LOPEZ, M.I.; FELDLAUFER, M.F.; WILLIAMS, A.D.; CHU, P.S. Determination and confirmation of nitrofuran residues in honey using LC-MS/MS. Journal of Agricultural and Food Chemistry, v.55, n.4, p.1103-1108, 2007.

MASTOVSKA, K. Multiresidue Analysis of Antibiotics in Food of Animal Origin Using Liquid Chromatography-Mass Spectrometry. In: ZWEIGENBAUM, J. (Ed.). Mass Spectrometry in Food Safety Methods and Protocols. Wilmington, DE: Humana Press - Springer: 2011. p.267-307.

MCCALLA, D.R.; REUVERS, A.; KAISER, C. Breakage of bacterial DNA by nitrofuran derivatives. Cancer Research, v.31, n.12, p.2184-2188, 1971.

MCCRACKEN, R.J.; KENNEDY, D.G. Detection, accumulation and distribution of nitrofuran residues in egg yolk, albumen and shell. Food Additives and Contaminants, v.24, n. 1, p.26-33, 2007.

NIESSEN, W.M.A. Liquid Chromatography-Mass Spectrometry. $3^{\text {rd }}$ ed. Taylor \& Francis, 2010. 600p.

ONA, K.R.; COURCELLE, C.T.; COURCELLE, J. Nucleotide excision repair is a predominant mechanism for processing nitrofurazoneinduced DNA damage in Escherichia coli. Journal of Bacteriology, v.191, n. 15, p.4959-4965, 2009.

PEREIRA, A.S.; DONATO, J.L.; DE NUCCI, G. Implications of the use of semicarbazide as a metabolic target of nitrofurazone contamination in coated products. Food Additives and Contaminants, v.21, n. 1, p.63-69, 2004.

PHONGVIVAT, S. Nitrofurans case study: Thailand's experience. In: FAO/WHO (Ed.). Technical Workshop on Residues of Veterinary Drugs Without ADI/MRL. Rome, Italy: FAO Publishing Management Service: 2004. p.125-149. 
RADOVNIKOVIC, A.; MOLONEY, M.; BYRNE, P.; DANAHER, M. Detection of banned nitrofuran metabolites in animal plasma samples using UHPLC-MS/MS. Journal of Chromatography $B$, v.879, n.2, p.159-166, 2011.

REIG, M.; TOLDRÁ, F. Veterinary drug residues in meat: Concerns and rapid methods for detection. Meat Science, v.78, n. 1-2, p.60-67, 2008.

SAARI, L.; PELTONEN, K. Novel source of semicarbazide: levels of semicarbazide in cooked crayfish samples determined by LC/MS/ MS. Food Additives and Contaminants, v.2 1, n.9, p.825-832, 2004.

SHANKAR, B.P.; MANJUNATHA PRABHU, B.H.; CHANDAN, S.; RANJITH, D; SHIVAKUMAR, V. Rapid methods for detection of veterinary drug residues in meat. Veterinary World, v.3, n.5, p.241-246, 2010.
TOLDRÁ, F.; REIG, M. Methods for rapid detection of chemical and veterinary drug residues in animal foods. Trends in Food Science (2) Technology, v.17, n.9, p.482-489, 2006.

VASS, M.; HRUSKA, K.; FRANEK, M. Nitrofuran antibiotics: a review on the application, prohibition and residual analysis. Veterinarni Medicina, v.53, n.9, p.469-500, 2008.

VERDON, E.; COUEDOR, P.; SANDERS, P. Multi-residue monitoring for the simultaneous determination of five nitrofurans (furazolidone, furaltadone, nitrofurazone, nitrofurantoine, nifursol) in poultry muscle tissue through the detection of their five major metabolites (AOZ, AMOZ, SEM, AHD, DNSAH) by liquid chromatography coupled to electrospray tandem mass spectrometry-In-house validation in line with Commission Decision 657/2002/EC. Analytica Chimica Acta, v.586, n. 1-2, p.336-347, 2007. 